\title{
GOING CONCERN AUDIT OPINION: THE ROLE OF AUDIT DELAY, OPINION SHOPPING, FINANCIAL DISTRESS, LEVERAGE AND SIZE OF COMPANY
}

\author{
Efrizal Syofyan ${ }^{1)}$, Kesi Okta Vianti ${ }^{2)}$ \\ Accounting Department, Economic Faculty, Universitas negeri Padang, Padang ${ }^{1,2)}$ \\ efrizal.syofyan@fe.unp.ac.id ${ }^{1)}$, kesioktavianti83@gmail.com ${ }^{2)}$
}

\begin{abstract}
This Research examines the role of audit delay, opinion shopping, financial distress, leverage, and company size on Going concern (GC) audit opinion. This research is classified as the causality research method. The research population is manufacturing companies listed on the Indonesia Stock Exchange (IDX) between 2016 and 2019. We used the purposive sampling method to choose the samples from the population. In the end, we got 124 samples. The data were obtained from www.idx.co.id. and other related websites. The study results show that audit delay, opinion shopping, leverage, and company size do not affect GC opinion. But, financial distress has a positive effect on GC opinion. These results give the knowledge about the factors that affect going concern audit opinion. Auditors as individuals who have independence are expected to be careful in issuing going-concern audit opinions. They should consider the factors that may affect their decision.
\end{abstract}

Keywords: Audit Delay; Opinion Shopping; Financial Distress; Leverage; Company Size; GC Opinion.

*Corresponding author :

Email: evi.maria@uksw.edu

DOI: https://doi.org/10.33369/j.akuntansi.11.3.235-246

\section{INTRODUCTION}

The primary way to inform its internal and external parties regarding its condition is through financial reports. Information contained in financial reports is essential in helping investors, and other stakeholders make decisions regarding investments, credit, and other resource allocations to increase overall market efficiency (Auladi et al., 2019). The quality of financial reports could decline because of the problems that may arise between principals and agents due to conflict of interest. When preparing financial reports, agents are often more concerned with their interests. Therefore, auditor independence is crucial in giving symmetrical information between the two parties. Independent auditors can disclose their opinion on the appropriateness of corporate financial reports. Thus, independent auditors' information is expected to help decision-making increase market efficiency for external parties (Syahputra \& Yahya, 2017).

Auditors are fully responsible for their own opinion on a financial reports company, whether $G C$ or non-GC opinion. The financial reports company would receive non-GC opinion if they comply with the generally accepted accounting standards; however, if the financial reports do not follow the generally accepted accounting standards, they will receive $G C$ opinion. Auditors are responsible for explaining why a company receives $G C$ opinion because this opinion is considered a concern for the company (Auladi et al., 2019).

Praptitorini and Januarti (2011) suggest that a common problem is a difficulty predicting the continuity of an entity, which causes a moral and ethical dilemma in many independent auditors when issuing $G C$ opinions. Investors would not invest in a company that receives a $G C$ opinion. Similarly, investors who have already invested in the company would withdraw their investments, which could quickly lead a company to bankruptcy. 
GOING CONCERN AUIDIT OPINION: THE ROLE OF AUDIT DELAY, OPINION SHOPPING, FINANCIAL DISTRESS, LEVERAGE AND SIZE OF COMPANY

Efrizal Syofyan and Kesi Okta Vianti

Table 1. List of Manufacturing Companies Delisted from IDX due to GC Problems 2016-2019

\begin{tabular}{|c|c|c|c|c|c|}
\hline Description & 2016 & 2017 & 2018 & 2019 & Total \\
\hline Quantity & 0 & 1 & 3 & 1 & \multirow{4}{*}{5} \\
\hline \multirow{3}{*}{$\begin{array}{l}\text { Company } \\
\text { Name }\end{array}$} & & $\begin{array}{l}\text { SOBI (Sorini Agro } \\
\text { Asia Corporindo Tbk) }\end{array}$ & $\begin{array}{l}\text { DAJK (PT Dwi Aneka } \\
\text { Jaya Kemasindo Tbk) }\end{array}$ & $\begin{array}{l}\text { SIAP (Sekawan } \\
\text { Intipratama Tbk) }\end{array}$ & \\
\hline & & & $\begin{array}{l}\text { JPRS (Jaya Pari Steel } \\
\text { Tbk) }\end{array}$ & & \\
\hline & & & $\begin{array}{l}\text { SQBB (Taisho } \\
\text { Pharmaceutical } \\
\text { Indonesia Tbk) }\end{array}$ & & \\
\hline
\end{tabular}

Table 1 above shows that five manufacturing companies experienced delisting from IDX due to $G C$ problems or problems with the company's continuity. Indonesia Stock Exchange Rule (Number: Kep-308/BEJ/07-2004 Number I-I) suggests that the exchange delete the listing companies following the conditions. If experiences a condition/event significantly has a negative effect on the Listed Companies, either financially or legally or the continuity of the status of Public Company, and the Listed Company cannot show any indication of adequate recovery; the stocks in the Listed Company is only traded in Negotiation Market at least within the last 24 months caused by the suspension in Regular Market and Money Market.

Following the decision mentioned above, SIAP Ltd is removed from the exchange due to poor company performance. Before being delisted, SIAP Ltd had also been suspended for more than two years. The exchange evaluates that SIAP is not $G C$ as per IDX requirements. The central business unit is considered insignificant in contributing to the company, thus showing the poor performance (www.kontan.co.id). Meanwhile, the DAJK delisting case is caused by the company's continuity that owes debts to several banks such as Mandiri Bank amounting to 428.27 billion, Standard Chartered Bank amounting to 262.42 billion, Commonwealth Bank amounting to 50.47 billion, and other banks. DAJK also has a recorded net loss amounting to 59.61 billion (www.cnbcindonesia.com)

These events show that it is inadequate only to disclose opinions on the appropriateness of corporate financial reports. Therefore, opinion on GC should also be disclosed to make an immediate effort in saving companies facing difficulties (Ginting \& Tarihoran, 2017). However, there are still many issues. This is explained in the agency theory in which management is reluctant to disclose uncertainties regarding the company's continuity, such as evaluating the management's share ownership or management's concerns regarding the reputation of the company in the global market in the future (Chapple et al., 2012). Generally, corporate management perceives the uncertainties of the GC of the company as bad news. Therefore, auditors are needed as an independent third party.

Auditors as independent parties must detect fraud and disclose the general information on corporate financial reports to avoid misleading decision-making. SA Section 341 states that auditors are also responsible for evaluating the existence of doubt concerning the company's age less than one year from issuing an audit report. As a result, auditors need to thoroughly evaluate its management plan to conclude whether or not a company is GC. GC problems are very complex and will always exist. Therefore factors are needed as a benchmark to determine the GC status of a company, and these factors need to be tested so that the GC status can still be predicted even in an unstable economic condition (Lestari \& Prayogi, 2017).

Many factors affect the GC opinion, and in this research, they are audit delay, opinion shopping, financial distress, leverage and company size. Research conducted by Auladi et al. (2019) found that audit delay significantly impacts the GC opinion. The research contrasts this carried out by Widoretno (2019), who found that audit lag does not impact the issuance of GC 
opinion. Likewise, Syahputra \& Yahya (2017) report that audit delay is not related to the GC opinion; however, opinion shopping impacts the GC opinion.

According to Simamora and Hendarjatno (2019) and the study conducted by Ramadhani and Sulistyowati (2020), opinion shopping influences the GC opinion. The study carried out by Kartika et al. (2012) finds that opinion shopping does not influence the GC opinion. Kesumojati et al. (2017) reported that financial distress has a significant effect on GC opinion. The study carried out by Dewi and Latrini (2018) also discovered that financial distress has a negative impact on GC opinion. On the other hand, Lestari \& Prayogi (2017) discovered that financial distress does not significantly impact the GC opinion.

The study conducted by Nursasi et al. (2015) and Aryantika \& Rasmini (2015) show that leverage influences the GC opinion. On the contrary, Wulandari et al. (2014) and Kadirisman (2018) stated that leverage ratio does not impact the GC opinion. Additionally, Rakatenda \& Putra (2016) and Rizkillah \& Nurbaiti (2018) concluded that size positively impacts the GC opinion. These results are not aligned with Wulandari et al. (2014) and Tandungan \& Mertha (2016), arguing that the company size does not significantly affect the GC opinion.

The existing literature shows diverging conclusions about factors affecting GC opinion. Moreover, most prior studies focused only on one or two factors affecting GC opinion. This research contributes by conducting a more comprehensive examination of GC opinion by incorporating the role of firms' characteristics and other factors, namely, audit delay, opinion shopping, financial distress, leverage, and company size on listed manufacturing companies from 2016 to 2019. The results show that financial distress significantly impacts GC opinion, whereas audit delay, opinion shopping, leverage, and company size do not significantly influence GC opinion. It shows that auditors in Indonesia are very much "play it safe and by the book" when facing indications of financial distress by issuing CG opinion as clearly dictated by audit standards.

This study intends to explore the effect of audit delay, opinion shopping, financial distress, leverage, and company size on the GC opinion. The benefit of this study for the researchers is to increase knowledge and insight on the aspects that impact the GC opinion. For auditors, this could help them be attentive in issuing the GC opinion to avoid mistakes that could impact the independence of the audit. For the place/object of study, this could help evaluate and change or improve what could be improved, help develop strategies, and be used as references.

Audit delay refers to the timespan of audit completion. The books are closed until the issued financial reports are different between dates of the financial reports and opinion. It indicates the duration of audit completion done by the auditor. The longer the audit delay, the greater the possibility of postponing opinion, and the more likely the manager would negotiate when business uncertainties are found. Therefore, the later audit reports are issued, the greater the possibility of the auditee having GC problems.

$H_{1}$ : Audit delay significantly and positively impact the GC opinion.

Opinion shopping is an activity that aims to find auditors willing to work together to support the management's accounting method to achieve its goals. Companies tend to switch auditors to avoid acquiring a GC opinion. Corporate managers are motivated to do opinion shopping because auditors are willing to achieve their goals and sustain the GC. Therefore, if a company often does opinion shopping, it is less likely to receive GC opinion.

$\mathrm{H}_{2}$ : Opinion shopping has a significant negative impact on the GC opinion.

Financial distress indicates significant uncertainties on the ability of a company to continue its operations. Companies that experience financial distress will have financial 
difficulties in fulfilling their obligations. Financial distress indicators can be seen from the financial performance obtained from the financial reports of accounting information. In financial reports, auditors may release the GC opinion to the company if a company suffers a loss in its annual net income while still having unfulfilled obligations. Therefore, there is a higher possibility that a company would get the GC opinion if they have a greater possibility of experiencing financial failure.

$H_{3}$ : Financial distress significantly and positively impact the GC opinion.

Leverage indicates the amount of company debt in comparison to the company assets. The company's ability to settle debt obligations shows its level of performance. A higher leverage ratio of a company, or the amount of debt compared to its ability to pay them back, would result in poorer company performance. It could arise uncertainties on the company's continuity, which results in a greater possibility of that company receiving a GC opinion.

$\mathrm{H}_{4}$ : Leverage has a significant positive impact on the GC opinion.

The size of a company could be calculated from its total assets, indicating the company's ability to maintain its continuity. A large amount of total assets shows that the companies are at a maturity stage caused by the already positive cash flow and have significant long-term prospects. They are also considered to be able to manage the company and produce excellent financial reports. Therefore, this concludes that large-sized companies would have less possibilities of receiving a GC opinion.

$\mathrm{H}_{5}$ : Size of company impacts the GC opinion significantly and negatively.

Independent Variables

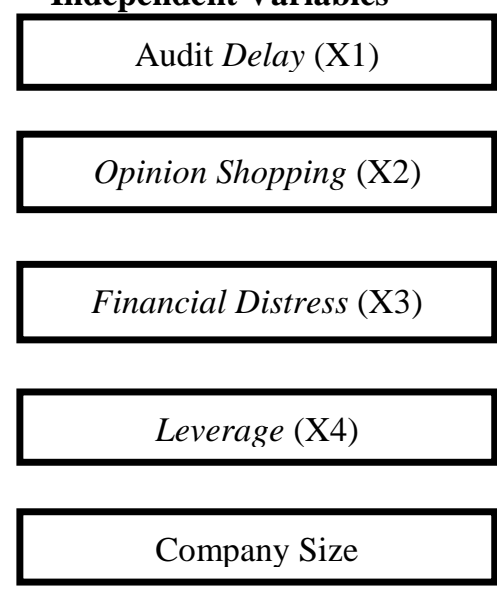

Dependent Variable

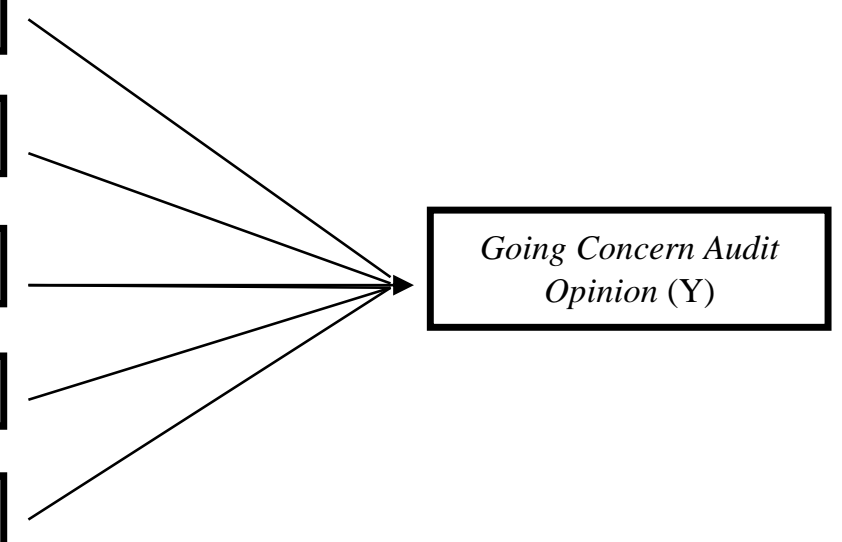

Figure 1. Conceptual Framework

\section{RESEARCH METHODS}

The study population is manufacturing companies recorded on IDX between the years 2016-2019. The purposive sampling method has criteria shown below:

1. The manufacturing companies registered in IDX between the years 2016-2019 and are not delisted.

2. Those companies provide complete financial reports from the year 2016-2019.

3. Those companies provide financial reports using rupiah from the year 2016-2019.

4. Those companies suffer net loss after tax for at least one period of the financial report within the study period (2016-2019). Net loss after tax is used to indicate the financial condition of companies that experience problems and have the tendency to acquire GC opinion. 
The data were acquired from the official IDX website (www.idx.co.id) and other websites related to the study. A sample of manufacturing companies are calculated as follows:

Table 2. Manufacturing Companies Sample Criteria

\begin{tabular}{lc}
\hline Number of manufacturing companies in IDX & 167 \\
\hline Those companies delisted from the year 2016 until 2019 & $(25)$ \\
\hline Those companies that do not serve complete financial reports from the year 2016-2019 & $(9)$ \\
\hline Those companies that do not provide financial reports using rupiah from the year 2016-2019 & $(27)$ \\
\hline Those companies that do not suffer net LOSS at least for one year within 2016-2019. & $(75)$ \\
\hline Total samples of manufacturing companies & 31 \\
\hline Source: Processed secondary data, 2020
\end{tabular}

The data type in this research is documentation data in financial reports and the daily price of manufacturing and monetary companies listed on IDX. Our data categories as secondary data were those acquired indirectly through intermediary media. Financial reports data and date of publication of financial reports are acquired from IDX official website (www.idx.co.id) and other relevant websites.

\section{Research Variables and Measurement}

The dependent variable is GC Opinion. The First variable is attributed to corporations that receive $\mathrm{GC}$ opinion, while value 0 is assigned for corporations that receive non-GC opinion. The first independent variable is audit delay calculated by the day's number between the dates of financial reports, which is December $31^{\text {st }}$ until the auditor report is issued. The second variable is opinion shopping, which uses a dummy variable where value 1 is assigned for companies audited by a different independent auditor in the following year after receiving a GC opinion. Value 0 is assigned for companies audited by the same auditor the following year after receiving a GC opinion. The third independent variable is financial distress. One of the prediction models for financial distress is stated by Abdullah et al. (2014), a model that Altman has developed. The result from the research developed by Altman is as shown below:

$Z^{\prime}=0,717 Z_{1}+0,874 Z_{2}+3,107 Z_{3}+0,420 Z_{4}+0,998 Z_{5}$

Notes:

$\mathrm{Z}<1,81=$ indicates prediction of bankruptcy

$1,81=\mathrm{Z}=2,99=$ indicates grey area

Z>2,99 = indicates no bankruptcy

Z1. Working capital/Total assets

$\mathrm{Z} 2$ = Retained Earnings/Total assets

Z3 _ Earnings before interest and taxes/Total assets

$\mathrm{Z} 4=$ Market value equity/Book value of total debt

$\mathrm{Z5}=$ Sales/Total assets

$\mathrm{Z}=$ Overall index

The fourth independent variable is leverage. Leverage ratio is calculated using Debt to Equity Ratio (DER) formula as follows:

Leverage Ratio $=\frac{\text { Total Liability }}{\text { Total Equity }}$

The last independent variable is the company size that is calculated using Log Natura total asset formulas as follows:

SIZE $=$ Ln Total Assets 
The data processing and analysis is logistic regression. This analysis is helped by Statistical Package for Social Science (SPSS) Ver. 23. The model used in this study is:

$\mathrm{GC}=\beta_{0}+\beta_{1} \mathrm{X}_{1}+\beta_{2} \mathrm{X}_{2}+\beta_{3} \mathrm{X}_{3}+\beta_{4} \mathrm{X}_{4}+\beta_{5} \mathrm{X}_{5}+\varepsilon$

Notes:

GC : GC Opinion

$\beta_{0} \quad$ : Constant

$\mathrm{X}_{1} \quad$ : Audit Delay

$\mathrm{X}_{2} \quad$ :Opinion Shopping

$\mathrm{X}_{3} \quad$ : Financial Distress

$\mathrm{X}_{4} \quad$ : Leverage

$\mathrm{X}_{5} \quad$ : Size of Company

$\beta_{1}-\beta_{5} \quad$ : Regression Coefficient

$\varepsilon \quad$ : Coefficient of Error

Furthermore, this study also conducted a feasibility test for the regression model, assessed the overall model and tested the coefficient of determination. Afterwards, this study also conducted hypothesis testing using a partial test (Wald test) and simultaneous test (F statistic test).

\section{RESULTS AND DISCUSSION Results}

The descriptive statistic table provides an overview regarding the characteristics of observed variables. Researchers used SPSS23, 2016, to process the data. The dependent variable is $\mathrm{GC}$ opinion ( 1 is attributed to corporations that receive GC opinion while value 0 is assigned for corporations that receive non-GC opinion). The first independent variable is audit delay that has a mean is 101.82. It means that the days between the dates of financial reports and the date in which auditor report is issued on average is 101.82 days. The second independent variable is pinion shopping, with the value " 1 ", meaning is assigned for companies audited by a different independent auditor in the following year after receiving a GC opinion. Value " 0 " is assigned for companies audited by the same auditor the following year after receiving a GC opinion. The third independent variable is financial distress that has a mean of $\mathrm{Z}$ score of 1.10639. So, on average, $\mathrm{Z}$ scores lower than 1.81 or indicates bankruptcy. The four independent variables are leverage that has a mean score of 3.46685. Last, the average size of the company is 14.09303 .

Table 3. Descriptive Statistics

\begin{tabular}{lccccc}
\hline & $\mathrm{N}$ & Min. & Max. & Mean & Std. Deviation \\
\hline $\mathrm{Y}$ & 124 & 0 & 1 & .31 & .466 \\
\hline $\mathrm{X} 1$ & 124 & 22 & 401 & 101.82 & 52.837 \\
\hline $\mathrm{X} 2$ & 124 & 0 & 1 & .06 & .247 \\
\hline $\mathrm{X} 3$ & 124 & -6.999 & 7.692 & 1.10639 & 2.150932 \\
\hline $\mathrm{X} 4$ & 124 & -5.285 & 162.184 & 3.46685 & 15.171678 \\
\hline $\mathrm{X} 5$ & 124 & 11.395 & 17.615 & 14.09303 & 1.414288 \\
\hline Valid N (listwise) & 124 & & & & \\
\hline Source: SPSS 23 & & & & &
\end{tabular}

\section{The goodness of Fit-Logistic Regression Analysis}

The purpose of this test is to examine the null hypothesis whether the empirical data fits the model (the lack of difference between model and data means that model can be considered fit). The hypothesis to evaluate the goodness of fit is as follows:

$\mathrm{H}_{0}$ : There is no variation between model and data (model fits data)

$\mathrm{H}_{\mathrm{a}}$ : There is a variation between model and data (the model does not fit data) 
Table 4. Hosmer and Lemeshow's Goodness of fit Test Hosmer and Lemeshow Test

\begin{tabular}{lccccr}
\multicolumn{5}{c}{ Hosmer and Lemeshow Test } \\
\hline Step & Chi-square & df & & Sig. \\
\hline 1 & 6.250 & 8 & & .619 \\
\hline Source: SPSS 23 & & & &
\end{tabular}

Table 4 displays the statistical value of Hosmer and Lemeshow's Goodness of fit Test of 0.619. The test results exceed 0.05, and the null hypothesis cannot be rejected. Thus, the model and observed data are identical because the model could predict the observation value, or it is safe to assume that the model can be accepted because it fits the observed data.

\section{Evaluating Overall Model}

The model fit test was carried out based on the Likelihood function. Likelihood L from the model refers to the probability that the hypothesized model portrays input data. Hypotheses used to evaluate the model fit are as follows:

Ho = Hypothesized model fits the data

$\mathrm{Ha}=$ Hypothesized model does not fit the data

Table 5 below displays the statistical value of -2 log-likelihood is 96.451 . Using Chisquare Table $\chi^{2}$ on Degree of Freedom $(\mathrm{N}-$ quantity of variable -1$)=120$ and $\alpha=0.05$ amounting to 146.5673 , which means the value of -2 log-likelihood is less than the value of Chi-square $\chi^{2}$ Table; therefore, $\mathrm{H}_{0}$ (null hypothesis) is accepted so that the hypothesized model matches the data.

Table 5. Overall Model Fit

\begin{tabular}{|c|c|c|c|c|c|c|c|c|}
\hline \multirow[t]{2}{*}{ Iteration } & & \multirow{2}{*}{$\begin{array}{c}-2 \log \\
\text { likelihood }\end{array}$} & \multicolumn{6}{|c|}{ Coefficients } \\
\hline & & & Constant & $\mathrm{X} 1$ & $\mathrm{X} 2$ & $\mathrm{X} 3$ & $\mathrm{X} 4$ & $\mathrm{X} 5$ \\
\hline \multirow{20}{*}{ Step 1} & 1 & 108.419 & 1.302 & .007 & -2.544 & -.330 & -.015 & .006 \\
\hline & 2 & 98.690 & 1.991 & .011 & -4.205 & -.579 & -.023 & .047 \\
\hline & 3 & 96.834 & 2.950 & .012 & -5.654 & -.744 & -.026 & .078 \\
\hline & 4 & 96.570 & 4.012 & .012 & -6.798 & -.789 & -.026 & .086 \\
\hline & 5 & 96.494 & 5.031 & .012 & -7.819 & -.792 & -.026 & .086 \\
\hline & 6 & 96.467 & 6.036 & .012 & -8.825 & -.792 & -.026 & .086 \\
\hline & 7 & 96.456 & 7.038 & .012 & -9.827 & -.792 & -.026 & .086 \\
\hline & 8 & 96.453 & 8.039 & .012 & -10.827 & -.792 & -.026 & .086 \\
\hline & 9 & 96.451 & 9.039 & .012 & -11.828 & -.792 & -.026 & .086 \\
\hline & 10 & 96.451 & 10.039 & .012 & -12.828 & -.792 & -.026 & .086 \\
\hline & 11 & 96.451 & 11.039 & .012 & -13.828 & -.792 & -.026 & .086 \\
\hline & 12 & 96.451 & 12.039 & .012 & -14.828 & -.792 & -.026 & .086 \\
\hline & 13 & 96.451 & 13.039 & .012 & -15.828 & -.792 & -.026 & .086 \\
\hline & 14 & 96.451 & 14.039 & .012 & -16.828 & -.792 & -.026 & .086 \\
\hline & 15 & 96.451 & 15.039 & .012 & -17.828 & -.792 & -.026 & .086 \\
\hline & 16 & 96.451 & 16.039 & .012 & -18.828 & -.792 & -.026 & .086 \\
\hline & 17 & 96.451 & 17.039 & .012 & -19.828 & -.792 & -.026 & .086 \\
\hline & 18 & 96.451 & 18.039 & .012 & -20.828 & -.792 & -.026 & .086 \\
\hline & 19 & 96.451 & 19.039 & .012 & -21.828 & -.792 & -.026 & .086 \\
\hline & 20 & 96.451 & 20.039 & .012 & -22.828 & -.792 & -.026 & .086 \\
\hline
\end{tabular}

Source: SPSS 23

\section{Coefficient of Determination Test}

The analysis was used to find how much the independent variable affects a dependent variable. This test can be seen from Negelkerke's R square statistical value. 
GOING CONCERN AUIDIT OPINION: THE ROLE OF AUDIT DELAY, OPINION SHOPPING, FINANCIAL DISTRESS, LEVERAGE AND SIZE OF COMPANY

Efrizal Syofyan and Kesi Okta Vianti

\begin{tabular}{|c|c|c|c|}
\hline Step & $\begin{array}{c}-2 \log \\
\text { likelihood }\end{array}$ & $\begin{array}{l}\text { Cox \& Snell R } \\
\text { Square }\end{array}$ & $\begin{array}{l}\text { Nagelkerke R } \\
\text { Square }\end{array}$ \\
\hline 1 & $96.451^{a}$ & .373 & .524 \\
\hline
\end{tabular}

The results show that the statistical value of Negelkerke's R square is 0.524 . It means that $52.4 \%$ of dependent variables could result from independent variables while other variables can explain the remaining $46.6 \%$, not within the research. If the statistical value approaches 1, then the effect of independent variables that include Audit Delay, Opinion Shopping, Financial Distress, Leverage and Size of Company on the GC Opinion is intense.

\section{Hypothesis Test \\ Partial Test}

A partial test is used to find which independent variable consequentially impacts the dependent variable. One of the statistical tests in logistical regression is the Wald test, which can test whether an independent variable has a partial impact on the dependent variable. Based on the calculations done on SPSS program version 23, the test result is shown as follows:

Table 7. Variables in the Equation

\begin{tabular}{clcccccc}
\hline & & $\mathrm{B}$ & S.E. & Wald & df & Sig. & $\operatorname{Exp}(\mathrm{B})$ \\
\hline \multirow{5}{*}{ Step $1^{\mathrm{a}}$} & $\mathrm{a} 1$ & .012 & .008 & 2.472 & 1 & .116 & 1.012 \\
\cline { 2 - 8 } & $\mathrm{X} 1$ & -22.828 & 12301.308 & .000 & 1 & .999 & .000 \\
\cline { 2 - 8 } & $\mathrm{X} 2(1)$ & -.792 & .220 & 12.953 & 1 & .000 & .453 \\
\cline { 2 - 8 } & $\mathrm{X} 4$ & -.026 & .018 & 2.000 & 1 & .157 & .974 \\
\cline { 2 - 8 } & $\mathrm{X} 5$ & .086 & .181 & .226 & 1 & .634 & 1.090 \\
\cline { 2 - 8 } & Constant & 20.039 & 12301.308 & .000 & 1 & .999 & 504580819.393 \\
\hline
\end{tabular}

Source: SPSS 23

The first hypothesis in this study is that audit delay significantly and positively impacts GC opinion. Table 7 signifies that audit delay shows a positive coefficient with a significance value higher than $\alpha=0.05$. It indicates that audit delay partially does not significantly impact GC opinion, and therefore it can be concluded that the first hypothesis is rejected.

The second hypothesis is opinion shopping significantly and negatively impacts GC opinion. Table 7 indicated that opinion shopping also indicates a positive coefficient with a significance value larger than $\alpha=0.05$. It shows that opinion shopping $\left(\mathrm{X}_{2}\right)$ partially does not significantly influence GC opinion, so in conclusion, the second hypothesis is rejected.

The third hypothesis is financial distress influence GC opinion significantly and positively. Table 7 shows that financial distress has a positive coefficient of 0.000 , less than $\alpha$ $=0.05$. It indicates that financial distress $\left(\mathrm{X}_{3}\right)$ partially has a positive and consequential impact on GC opinion. So, our H3 is supported.

The fourth hypothesis is leverage has a significant positive effect on GC opinion. According to Table 7, leverage also shows a positive coefficient with a significance value of more than $\alpha=0.05$. It suggests that leverage $\left(\mathrm{X}_{4}\right)$ partially does not significantly impact the GC opinion, and this allows the conclusion that the fourth hypothesis is rejected.

The fifth hypothesis is company size has a significant negative impact on GC opinion. According to Table 7, company size also shows a positive coefficient with a significance value of more than $\alpha=0.05$. It suggests that the company's size $\left(\mathrm{X}_{5}\right)$ partially does not consequentially impact the GC opinion. Therefore the fifth hypothesis is rejected.

In conclusion, with a significance level of $5 \%$, the independent variable financial distress partially influences the GC opinion, which means the third hypothesis is accepted. 
Audit delay, opinion shopping, leverage, and size of a company partially do not significantly affect the GC opinion, which means the first, second, fourth and fifth hypotheses are rejected.

\section{Simultaneous Test}

A simultaneous test aims to see the impact of the three independent variables on the dependent variable simultaneously. The statistical test used is the result of the omnibus test of model coefficient testing. The results of the testing are shown in the table below.

Table 8. Omnibus Test of Model Coefficient

\begin{tabular}{ccccc}
\hline & & Chi-square & df & Sig. \\
\hline \multirow{3}{*}{ Step 1 } & Step & 400,639 & 1 &, 000 \\
\cline { 2 - 5 } & Block & 400,639 & 1 &, 000 \\
\cline { 2 - 5 } & Model & 400,639 & 1 &, 000 \\
\hline \multirow{3}{*}{ Step 2 } & Step & 17,863 & 1 &, 000 \\
\cline { 2 - 5 } & Block & 418,502 & 2 &, 000 \\
\cline { 2 - 5 } & Model & 418,502 & 2 &, 000 \\
\hline
\end{tabular}

Source: SPSS 23

Based on Table 8 , it can be seen that the Chi-square $\left(\chi^{2}\right)$ value of 418,502 is smaller than the Chi-square $\left(\chi^{2}\right)$ Table in DF 2, which is 5.991 or with a significance of 0.000 so that it rejects $\mathrm{H} 0$, which indicates that the addition of independent variables can have a natural effect on the model.

\section{Discussion}

\section{The Impact of Audit Delay on GC Opinion}

Our results show that the audit delay variable indicates a positive coefficient with sig. value of 0.344 (greater than $\alpha, 0.05$ ). It suggests that partially audit delay does not significantly impact GC opinion, and therefore $\mathrm{H} 0$ is rejected. The results show that a long period of audit completion in a company does not necessarily suggest GC problems and that the companies with prolonged audit delay would not necessarily acquire a GC opinion.

In our study, we found that audit delay did not have an impact on audit delay. We argue that companies may experience audit delays due to other factors. Such as auditors needing a long time because there are a lot of tests to be conducted and not because management is negotiating with the auditors regarding GC opinion or waiting for management to resolve the GC problems first to avoid issuing a GC opinion. These results comply with the previous studies that state that audit delay does not have a consequential impact on the GC opinion (Simamora \& Hendarjatno, 2019; Syahputra \& Yahya, 2017; Widoretno, 2019)

\section{The Impact of Opinion Shopping on GC Opinion}

Based on the testing, the opinion shopping variable has a positive coefficient with a sig. Value of 0.999 (more significant than $\alpha=0.05$ ) means that partially opinion shopping has no major impact on $\mathrm{GC}$ opinion; so $\mathrm{H}_{0}$ is rejected, meaning that changing the auditors by the companies after they receive GC opinion does not influence the GC opinion. Although a company often changes auditors after receiving GC opinion, it is still unclear whether this reflects opinion shopping practices. After receiving a GC opinion in the preceding year, many companies change their auditor and still receive GC opinion in the following year. Therefore, although a company changes their auditor after getting a GC opinion in the preceding year, the new auditor would still release a GC opinion if there is reasonable doubt in the corporation's ability to continue as a GC. This research result is supported by Kartika (2012) and Praptitorini \& Januarti (2011), who state that opinion shopping does not significantly impact the GC opinion. 


\section{The Impact of Financial Distress on GC Opinion}

The results above show that financial distress has a positive coefficient with a significance value of 0.000 (lower than $\alpha=0.05$ ) which means that partially, financial distress has a considerable impact on the reception of $\mathrm{GC}$ opinion and thus, $\mathrm{H}_{0}$ is accepted. Auditors pay close attention to the financial condition of a company when giving GC opinion. Companies that go through financial distress are undergoing financial issues, liquidity difficulties, inadequate working capital, and continuous losses, thus causing greater possibilities for the company to receive GC opinion. The greater the possibility of the financial failure of a company, the greater the possibility for them to obtain a GC opinion.

This result matches the study conducted by Rahim (2017), who reported that financial distress influences the GC opinion. A good financial condition can affect the continuity of a business. The continuity of a business is always equated with management's ability to manage the company to ensure its continuity. When a company experiences a problem (financial distress), the corporate operational activities will be hampered, increasing risks faced by the company when maintaining perpetuity in the following years. It then would affect the opinion given by the auditor. Likewise, Ramadhani \& Sulistyowati (2020) state that financial distress affects the GC opinion. The greater the difficulty level of the company's financial condition, the more excellent the opportunity for the company to receive a GC opinion.

\section{The Impact of Leverage on GC Opinion}

From the variable test results, it can be inferred that leverage has a positive coefficient with a significance value of 0.157 (higher than $\alpha=0.05$ ). It means that partially leverage does not significantly impact the $\mathrm{GC}$ opinion, and thus $\mathrm{H}_{0}$ is rejected. Although the leverage value of a company may be high, they would possibly not get GC opinion from the auditors. It may happen because increased debt could be followed by increased working capital; thus, the company's condition remains well.

According to Wulandari et al. (2014), leverage ratio also does not affect the GC opinion. It's due to the company's ability to manage its assets efficiently to increase sales growth every year. If the sales increase each year, the company will have funds to fulfil its obligations. There is in line with the study performed by Kadirisman (2018) and Sari \& Rahayu (2015), reporting that leverage does not influence the GC opinion.

\section{The Impact of Size of Company on GC Opinion}

Based on the variable test results, company size has a positive coefficient with a significance value of 0.634 (more significant than $\alpha=0.05$ ). It means that partially company size now has a considerable impact on the GC opinion, so H0 is rejected. It shows that large companies cannot necessarily guarantee their business continuity; likewise, small companies that cannot necessarily guarantee their business continuity could receive GC opinion. In the stakeholder theory, managers may be impacted by the stakeholders in managing their company. The more prominent company with the competence management in managing the business could maintain and manage the company assets well. This test result is supported by studies carried out by Kadirisman (2018), Tandungan \& Mertha (2016) and Wulandari et al. (2014), who reported that company size does not influence the GC opinion.

\section{CONCLUSIONS AND SUGGESTION}

This study examines the role of audit delay, opinion shopping, financial distress, leverage, and company size on Going concern (GC) audit opinion. The results show that audit delay, opinion shopping, leverage, and company size does not affect GC opinion. And, the 
financial distress has a positive effect on GC opinion.

This research has limitations that may weaken the results. The research population only utilizes manufacturing companies registered on IDX. Then, years of observation only run from 2016 to 2019 . The study period is only four years; thus, it cannot determine the long-term trend of GC opinion issuance by auditors. Also, this study only uses five variables: audit delay, opinion shopping, financial distress, leverage, and company size.

Future studies are expected to conduct further research regarding GC opinion by adding variables other than audit delay, opinion shopping, financial distress, leverage, and company size. Future researchers could extend the study period and are hoped to increase the population to all types of industries listed on IDX. Investors are advised to evaluate the continuity of corporate activities and the company's value by taking the significance factor of GC opinion before investing. Companies are advised to recognize early signs of business bankruptcy by conducting financial reports analysis; they can take actions as soon as possible to avoid those problems.

\section{REFERENCES}

Abdullah, S. N., Che A Halim, N. F., \& Puat Nelson, S. (2014). The Impact of New Regulations on Earnings Quality Among Malaysian Firms. International Journal of Economics, Management and Accounting, 22(2 SE-Articles). https://journals.iium.edu.my/enmjournal/index.php/enmj/article/view/270

Aryantika, N., \& Rasmini, N. (2015). Profitabilitas, Leverage, Prior Opinion Dan Kompetensi Auditor Pada Opini Audit Going Concern. E-Jurnal Akuntansi Udayana, 11(2), 414-425. https://ojs.unud.ac.id/index.php/Akuntansi/article/view/11020

Auladi, I. A. T., Azizah, D., Suwaji, D. W., \& Harventy, G. (2019). Pengaruh Audit Delay, Reputasi Auditor terhadap Penerimaan Opini Audit Going Concern (Studi Empiris pada Perusahaan Property dan Real Estate yang Terdaftar di Bursa Efek Indonesia Tahun 20152017). Jurnal Akademi Akuntansi, 2(2), 93-103.

Chapple, L. L., Kent, P., \& Routledge, J. (2012). Board Gender Diversity and Going Concern Audit Opinions. SSRN Electronic Journal, February. https://doi.org/10.2139/ssrn.1979040

Dewi, D. A. N. S., \& Latrini, M. Y. (2018). Pengaruh Financial Distress dan Debt Default pada Opini Audit Going Concern. E-Jurnal Akuntansi, 22(2), 1223-1252. https://doi.org/10.24843/EJA.2018.v22.i02.p15

Ginting, S., \& Tarihoran, A. (2017). Faktor-Faktor yang Mempengaruhi Pernyataan Going Concern. Jurnal Wira Ekonomi Mikroskil, 7(1), 9-20. https://www.mikroskil.ac.id/ejurnal/index.php/jwem/article/view/439/220

Kadirisman, I. (2018). Pengaruh Profitabilitas, Leverage, Kondisi Keuangan Dan Ukuran Perusahaan Terhadap Opini Audit Going Concern. Buletin Ekonomi, 9(1). http://ejournal.janabadra.ac.id/index.php/jurnalefektif/article/view/660/468

Kartika, A. (2012). Pengaruh Kondisi Keuangan Dan Non Keuangan terhadap Penerimaan Opini Going Concern Pada Perusahaan Manufaktur di BEI. Dinamika Akuntansi $\begin{array}{llll}\text { Keuanagn } \& \text { Perbankan, } & \text { 25-40. }\end{array}$ https://www.unisbank.ac.id/ojs/index.php/fe9/article/view/917

Kesumojati, S. C. I., Widyastuti, T., \& Darmansyah, D. (2017). Pengaruh Kualitas Audit, Financial Distress, Debt Default Terhadap Penerimaan Opini Audit Going Concern. JIAFE (Jurnal Ilmiah Akuntansi Fakultas Ekonomi), 3(1), 62-76. https://doi.org/10.34204/jiafe.v3i1.434

Lestari, P., \& Prayogi, B. (2017). Pengaruh Finacial Distress , Disclosure, dan Opini Audit 
Tahun Sebelumnya Terhadap Opini Audit Going Concern. Profita, 10(3), 388-398. https://doi.org/http://dx.doi.org/10.22441/journal\%20profita.v10i3.2838

Nursasi, Enggar, \& Maria, E. (2015). Pengaruh Audit Tenure, OpinionShopping, Leverage dan Pertumbuhan Perusahaan Terhadap Penerimaan Opini Audit Going Concern Pada Perusahaan Perbankan dan Pembiayaan yang Go Public di Bursa Efek Indonesia. JIBEKA, 9(1), 37-43. https://doi.org/https://doi.org/10.32812/jibeka.v9i1

Praptitorini, M. D., \& Januarti, I. (2011). Analisis Pengaruh Kualitas Audit, Debt Default Dan Opinion Shopping Terhadap Penerimaan Opini Going Concern. Jurnal Akuntansi Dan Keuangan Indonesia, 8(1), 78-93. https://doi.org/10.21002/jaki.2011.05

Rahim, S. (2017). Pengaruh Kondisi Keuangan Perusahaan, Kualitas Audit dan Opinion Shopping Terhadap Penerimaan Opini Going Concern. Jurnal Ilmiah Akuntansi Dan Bisnis, 75. https://doi.org/10.24843/jiab.2016.v11.i02.p02

Rakatenda, G. N., \& Putra, I. W. (2016). Opin Audit Going Concern dan Faktor - Faktor yang Mempegaruhinya. E-Jurnal Akuntansi Universitas Udayana, 16(2), 1347-1375. https://ojs.unud.ac.id/index.php/Akuntansi/article/view/20244

Ramadhani, F. T., \& Sulistyowati, W. A. (2020). Detection of Going Concern Audit Opinion Based on Disclosure, Financial Condition and Opinion Shopping. Jurnal Ilmiah Akuntansi Universitas Pamulang, 8(1), 75. https://doi.org/10.32493/jiaup.v8i1.3563

Rizkillah, S. T., \& Nurbaiti, A. (2018). Pengaruh Ukuran Perusahaan, Financial Distress, Profitabilitas, dan Opini Audit Tahun Sebelumnya Terhadap Pemberian Opini Audit Going Concern (Studi Empiris Pada Perusahaan Pertambangan yang Terdaftar di Bursa Efek Indonesia Tahun 2012-2016). Jurnal Akrab Juara, 3(3), 205-217.

Sari, D. I., \& Rahayu, S. (2015). Pengaruh Rasio Likuiditas, Leverage, Profitabilitas, Dan Pertumbuhan Perusahaan Terhadap Penerimaan Opini Audit Modifikasi Going Concern (studi Pada Perusahaan Manufaktur Yang Terdaftar Pada Bursa Efek Indonesia Selama Periode Tahun 2012-2014). EProceedings of Management, 2, 3.

Simamora, R. A., \& Hendarjatno, H. (2019). The effects of audit client tenure, audit lag, opinion shopping, liquidity ratio, and leverage to the going concern audit opinion. Asian Journal of Accounting Research, 4(1), 145-156.

Syahputra, F., \& Yahya, M. R. (2017). Pengaruh Audit Tenure, Audit Delay, Opini Audit Tahun Sebelumnya dan Opinion Shopping terhadap Penerimaan Opini Audit Going Concern pada Perusahaan .... Jurnal Ilmiah Mahasiswa Ekonomi Akuntansi (JIMEKA), 2(3), 39-47. https://www.neliti.com/publications/186935/pengaruh-audit-tenure-auditdelay-opini-audit-tahun-sebelumnya-dan-opinion-shopp

Tandungan, D., \& Mertha, I. M. (2016). Pengaruh Komite Audit, Ukuran Perusahaan, Audit Tenure, dan Reputasi KAP terhadap Opini Audit Going Concern. E-Jurnal Akuntansi Universitas Udayana, 16(1), 45-71. https://ojs.unud.ac.id/index.php/Akuntansi/article/view/14366

Widoretno, A. A. (2019). Factors That Influence The Acceptance of Going Concern Audit Opinion on Manufacture Companies. Journal of Economics, Business, and Government Challenges, 2(1), 49-57. https://doi.org/10.33005/ebgc.v2i1.64

Wulandari, S., Syarif, U., \& Jakarta, H. (2014). Analisis Faktor-Faktor Yang Mempengaruhi Auditor Dalam Memberikan Opini Audit Going Concern. Jurnal Akuntansi Universitas Udayana, 6(3), 531-558. https://ojs.unud.ac.id/index.php/Akuntansi/article/view/8350. 